\title{
Applying Past Lessons Learned to the Relocation of Climate Change Induced Transboundary Displaced Persons
}

\author{
Mikiyasu Nakayama (Corresponding author) \\ Graduate School of Frontier Sciences, The University of Tokyo \\ 5-1-5 Kashiwano-ha, Kashiwa, Chiba 277-8563, Japan \\ Tel: 81-4-7136-4869 Fax: 81-4-7136-4842Ｅ-mail: nakayama@k.u-tokyo.ac.jp
}

\author{
Hirotaka Fujibayashi \\ Graduate School of Frontier Sciences, The University of Tokyo \\ 5-1-5 Kashiwano-ha, Kashiwa, Chiba 277-8563, Japan \\ E-mail: h.fujibayashi13@gmail.com
}

Nagisa Yoshioka

Graduate School of Frontier Sciences, The University of Tokyo

5-1-5 Kashiwano-ha, Kashiwa, Chiba 277-8563, Japan

E-mail: 6272167605@edu.k.u-tokyo.ac.jp

Received: July 9, 2016 Accepted: August 9, 2016 Published: September 19, 2016

doi:10.5296/ijssr.v4i2.9718 URL: http://dx.doi.org/10.5296/ijssr.v4i2.9718

\begin{abstract}
This study aims to identify a useful and practical methodology to rehabilitate the livelihoods of climate change induced transboundary displaced persons (CCITDP) after they move to developed nations, in particular those from the Small Island Developing States in the Pacific Ocean. Migration sometimes causes conflicts among migrants, or between migrants and those in the host community. Such conflicts could be avoided or mitigated by examining the
\end{abstract}


lessons learned from people's past resettlement experiences-from those displaced by large infrastructure development projects in Asia and the Pacific or from evacuees of Fukushima due to the nuclear power plant disaster - and using these experiences to better cope with the emergence of CCITDP. Evacuees of an island that is sinking due to sea-level rise may be regarded as either voluntary migrants or CCITDP depending on when they leave the island. Although, lower-class people, who are vulnerable to hardships, will need to leave their homes earlier than wealthier people. These two groups of migrants should be assisted equally to avoid conflicts between the two groups because they may live in the same place after relocation and also to discourage them from staying on the island until they are entitled to assistance as CCITDP. Not all migrants will miss family bonds after relocation, and some may actually enjoy their emancipation from old customs by moving to a new place. The best destination for the first generation of migrants may differ from the best destination for their children.

Keywords: climate change, displaced, livelihood, migration, relocation, sea-level rise, Small Island Developing States

\section{Introduction}

\subsection{Addressing the Livelihood Rehabilitation of CCITDP}

The issue of so-called "climate refugees", or climate change induced transboundary displaced persons (CCITDP) in this article, has become a global concern. The massive inflow of the Syrian refugees to Turkey and European countries is supposed to stem from combination of climate change and bad government policies, which destroyed farming systems of the nation (Wendle, 2015). The concept CCITDP is not new. It emerged even before the establishment of the Intergovernmental Panel on Climate Change as a subset of environmental refugees. El-Hinnawi (1985) suggested the following definition for environmental refugees: "People who have been forced to leave their traditional habitat, temporarily or permanently, because of a marked environmental disruption (natural and/or triggered by people) that jeopardized their existence and/or seriously affected the quality of their life" (p. 4). The importance of the classification of CCITDP was signified in an article by Biermann and Boas (2010), which calls for "global adaptation governance" (p. 60) to address the proper resettlement of millions of CCITDP.

This study addresses the livelihood restoration of CCITDP who are obliged to flee from their home countries as a result of climate change. In particular, this study focuses on future migrants from the Small Island Developing States (SIDS) in the Pacific (e.g., Tuvalu, the Republic of the Marshall Islands, the Republic of Kiribati, etc.) due to the anticipated sea-level rise. It should be noted that climate change impacts SIDS earlier than non-island states. Migration from SIDS to other nations therefore needs to be addressed by the international society, which "increasingly is seen as part of adaptation rather than a failure to adapt" (Betzold, 2015; p481). The migration from SIDS to other nations due to sea-level rise also has some unique characteristics (Nakayama, Yoshioka, Fujibayashi \& Bruch, 2016) among CCITDP as a group. 
As is the case with all forced migrants, a smooth rehabilitation of the livelihoods of CCITDP after their relocation is of utmost importance.

Migration sometimes causes conflict among migrants, or between migrants and those in the host community. Reuveny (2007) examined 38 cases of climate change-induced migration and observed intrastate, interstate, or inter-communal conflicts in 19 of those cases, and the emergence of such conflicts is counterproductive to the livelihood rehabilitation of CCITDP after relocation. The lessons learned from these cases should be taken into consideration to develop programs to help CCITDP to reestablish their livelihoods successfully after relocation.

\subsection{Lessons from Past Infrastructure Development Projects and Evacuees of the Fukushima Daiichi Nuclear Power Plant Disaster}

The Asian Development Bank (2012) pointed out that increasing numbers of people are being resettled as the result of large infrastructure development projects in Asia and the Pacific; between 1986 and 1993, as shown in Table 1, the World Bank funded five dams that displaced between 100,001 and 200,000 people each (World Bank, 1996). This number surpasses the populations of some countries in the Pacific, like Tuvalu $(9,000)$, the Republic of the Marshall Islands $(52,000)$, or the Republic of Kiribati $(92,000)$, which are predicted to be submerged in 30 to 50 years due to the anticipated increase in sea-level brought about by climate change. We do not intend for these figures to discount the difficulty of CCITDP' relocation, but instead they will highlight how these past experiences of addressing resettlement could be applied to dealing with CCITDP.

Table 1. Number of People Displaced by Dams Funded by the World Bank from 1986 to 1993

\begin{tabular}{rlrr}
\hline Range of People Displaced & $\begin{array}{l}\text { Projects with } \\
\text { (number) }\end{array}$ & Resettlement & People Displaced (number) \\
\hline $100,001-200,000$ & 5 & 806,000 \\
$40,001-100,000$ & 6 & 307,000 \\
$10,001-40,000$ & 27 & 591,000 \\
$1,001-10,000$ & 58 & 243,000 \\
$501-1,000$ & 12 & 10,000 \\
$0-500$ & 38 & 6,000 \\
Total & 146 & $1,963,000$ \\
\hline
\end{tabular}

Source: World Bank (1996).

CCITDP bear some resemblance to those who are obliged to relocate involuntarily due to 
submergence of their homes by dam construction in that these two groups of forced migrants have no way to return home once they have left. They also have, relatively speaking, a longer time to plan for their relocation compared to evacuees of natural disasters (e.g., earthquakes, hurricanes, or tsunamis) or industrial accidents. We can obtain useful insights for dealing with CCITDP from the lessons learned through past dam construction projects.

Important and useful lessons may be also secured out of natural disasters and industrial accidents. This study addresses the latter, which was induced by the former. To be more specific, the lessons from the evacuees of the Fukushima Prefecture due to the explosion at the Fukushima Daiichi Nuclear Power Plant are considered.

More than five years have passed since the Great East Japan Earthquake, which took place on March 11, 2011, and the subsequent explosion at the Fukushima Daiichi Nuclear Power Plant. As many as 164,865 people were evacuated from their homes, and although the number of evacuees had decreased to fewer than 100,000 as of December 2015, many people are still displaced (The Japan Times, 2016).

It should be noted that some evacuees will never return home voluntarily, regardless of whether it is legal and safe to do so. We carried out interviews from 2013 to 2016 with the evacuees of the town of Hirono in the Fukushima Prefecture who were living in temporary housing in the city of Iwaki (also in the Fukushima Prefecture). Many of them found life in the temporary housing both enjoyable and efficient, to the extent that they have become reluctant to return home. Their reasons for feeling this way should be regarded as important lessons to be learned to better address the livelihood rehabilitation of CCITDP.

\section{Objectives and Methodology of This Study}

This study aims to determine a useful and practical methodology to deal with the rehabilitation of CCITDP's livelihoods. In addition to literature surveys, we scrutinized the accumulated past experiences of involuntary migrants due to dam construction projects (as well as their livelihood re-establishment) by revisiting studies we and our associates had previously conducted: Nakayama, 1998; Nakayama and Fujikura, 2014; Nakayama, Yoshida, and Gunawan, 2000; and Souksavath and Nakayama, 2013.

We also conducted interviews with about 50 Fukushima evacuees from Hirono who are living in temporary housing in Iwaki as well as Hirono government officials from 2013 to 2016.

Finally, we conducted interviews with the officers of relevant organizations dealing with migrants, including the United Nations High Commissioner for Refugees, the International Organization for Migration, and the International Federation of Red Cross and Red Crescent Societies, in order to find out how they have tried to help both forced and voluntary migrants reestablish their livelihoods.

\section{Results}

\subsection{Rationale of Making a Distinction Between Voluntary Migrants and CCITDP}

We wondered why some existing studies proposed a distinction between voluntary migrants 
and involuntary migrants due to environmental degradation such as climate change. This is related to the question of whether we should extend existing legal frameworks such as the 1951 Refugee Convention, the Geneva Conventions, or the Universal Declaration of Human Rights to CCITDP (Durková, Gromilova, Kiss, \& Plaku, 2012). Some researchers propose to protect CCITDP within these existing legal frameworks, but others have suggested creating a new treaty or an agreement related to the United Nations Framework Convention on Climate Change (Webber \& Barnett, 2010). As the arguments made in the past suggest, distinguishing environmental displacement from voluntary migration and defining a climate change refugee are critical first steps toward creating an appropriate framework for policy response (Oliver-Smith \& Shen, 2009). The fact is that although "protection gaps"-whether or not somebody offer a helping hand-exist between voluntary and involuntary migrants, many organizations provide relief and development support, and these organizations require a clear definition of CCITDP in order to distinguish between those who are entitled to international assistance (Kolmannskog, 2008).

\subsection{Risks of Differentiating Assistance}

The duration between the first and last refugees to leave their homes, specifically for refugees of slow-onset events, could be as long as a few decades (Nakayama, Yoshioka, Fujibayashi \& Bruch, 2016). In cases like these, the first to leave may be regarded as voluntary migrants rather than as refugees whereas the last to leave should be regarded as CCITDP, for their lives would be threatened if they were to stay in their homes. Kolmannskog (2008) also suggested that at first, people will migrate voluntarily because of insufficient income or employment opportunities. As time passes, however, migration tends to be purely for survival. Distinguishing between voluntary migrants and CCITDP may sound reasonable, for the latter needs assistance from the international community whereas this is not necessarily the case with the former. However, we suggest that making this distinction should not lead to different assistance, because we see it as one of the major lessons learned from the Fukushima evacuees following the Fukushima Daiichi Nuclear Power Plant explosion.

We witnessed very severe hostility between the residents of Iwaki and the evacuees from Hirono. Although both municipalities are located in the Fukushima Prefecture and are side-by-side, the way the residents of each were compensated (or not compensated) differed greatly.

As a matter of principle, compensation was given to those who lived within 30 kilometers of the Fukushima Daiichi nuclear reactor. As a consequence, those in Hirono were compensated whereas the citizens of Iwaki were not, creating conflicts between the evacuees from Hirono and the citizens of Iwaki. Because all the temporary housing for the evacuees was built in Iwaki, the evacuees living in the temporary housing were literally surrounded by the citizens of Iwaki and were forced to cohabitate with them. It turned out that some (if not all) Iwaki citizens were hostile toward the evacuees from Hirono to the extent that some witnessed Iwaki citizens committing vandalism (specifically damaging automobiles) against the evacuees from Hirono.

The sentiment of those in Iwaki was, "Why should only those from Hirono be compensated? 
Why we are not entitled to compensation? We used to be side-by-side and we are now in the same locality." Whether the Iwaki citizens' argument that they should also have been compensated, even to a lesser extent than those from Hirono, is justified or not may be a question better left unanswered.

It is not hard to imagine that conflicts of the same or similar nature may occur if assistance is differentiated between voluntary migrants and CCITDP when migrants from both groups relocate to the same community. As observed in Iwaki, the presence of such hostility is counterproductive to the migrants' livelihood rehabilitation in their destination (presumably a city in a developed country). The migrants need much more time than otherwise to be integrated into the host society with presence of such hostility. It is essential that there is no difference between the assistance given to voluntary migrants and CCITDP; the priority should be facilitating the migrants' livelihood rehabilitation in their destination through collaboration. Distinguishing between voluntary and involuntary migrants may be necessary for administrative and other purposes, but the people on both sides of this distinction should be treated equally.

\subsection{People May Be Motivated to Stay}

Many evacuees from Hirono remained in temporary housing after the order to leave town even though their houses were intact and they could return home if they so wished. One of the major reasons they remained in the temporary housing was because many of them believed that this was a condition to receive additional compensation. Their behavior reflects what they believed to be the best strategy for receiving any additional compensation.

The residents of a sinking island country may try to stay in their homes as long as possible in order to be recognized as CCITDP rather than voluntary migrants, even though such a delay in relocation may prove counterproductive. Staying in their homeland until the last minute may result in hardships for them and, in particular, their children. No major investment will be made in a sinking country, which may lead to the deterioration of living conditions and services such as education, medical services, and welfare.

This resistance to relocation would also incur additional expenditures in the refugees' home country, which may have a very limited budget and manpower as the situation worsens. Relocating sooner may be the best option for CCITDP to smoothly reestablish their livelihoods in their destination; Faist and Schade (2013) suggested that people should voluntarily relocate sooner in a well-organized manner rather than being forced into a hasty, disorganized move later on. Differentiating the assistance between voluntary migrants and CCITDP may be counterproductive in the above-mentioned contexts.

\subsection{Lower-Class People Need to Leave Earlier}

There is some evidence that in the event of slow-onset environmental changes, the propensity to relocate is related to land holdings. Those who have secure access to better land are supposed to be less prone to leave, and in many cases they belong to the upper class (EACH-FOR, 2008; Kothari, 2003; McLeman \& Smit, 2006; Mutton \& Haque, 2004). This has caused us to investigate what kinds of people will move in the earlier stages when climate 
change stimulates human migration.

Climate change is generally understood as having the most immediate and severe effect on people's basic needs and rights in those parts of the world where low-income and resource-dependent communities are living (Webber \& Barnett, 2010). It is reasonable to assume that those who live in such vulnerable areas are more likely to be exposed to climate-related risks earlier than upper-class people living in less susceptible areas.

In most cases, those who may move in response to environmental changes belong to the lower-middle classes and may only have enough money to move to a nearby area, not enough to move farther away (Krokfors, 1995; Skeldon, 2002; Skeldon, 2014). In order for people to move long distances, they need to have financial resources to some extent, and so the poorest people, who have no capacity to move, may be left behind (Warner \& Laczko, 2008). Therefore, we cannot make the sweeping statement that lower-income people move earlier than higher-income people.

However, the money these lower-class people possess may not be all the money available to them. For example, Hossain, Sarker, and McIntosh (2013) suggested that many official and unofficial agents operate to facilitate migration for those in the developing world. Generally speaking, such assistance is often designed for lower-class people; therefore, the presence of this assistance may enable poorer people to leave their homes much earlier than wealthier residents.

On account of the above-mentioned reasons, the relatively lower-class may flee earlier than the upper-class, in which case the former would be regarded as voluntary migrants and would be unable to receive any additional assistance that they might need to rehabilitate their livelihood. On the other hand, the latter would be recognized as CCITDP and may be entitled to more generous assistance. In other words, in such a situation, the upper-class migrants may receive generous assistance while the lower-class migrants would not be entitled to such assistance.

\subsection{Implications of Maintaining Family Bonds}

Minas et al. (2013) evaluated strong family bonds, religion, and traditional values positively, for these factors appeared to decrease the risk of suicide among immigrant and refugee communities in Australia. This would seem to indicate that maintaining strong family bonds may be desirable for smooth rehabilitation of CCITDP' livelihoods after relocation; however, attention should be paid to the fact that (a) strong family bonds may not always facilitate incorporation of immigrants into the host community, and (b) emancipation from family bonds may even serve as a driving factor for relocation for some CCITDP.

The WHO (2016) reported that Fukushima evacuees suffered from, among other things, disconnected family ties. While the WHO acknowledged the presence of such hardships among the displaced, it should be pointed out that some evacuees viewed these broken family ties rather positively. Some evacuees expressed to us that they felt emancipated from old, conventional social customs under which they had suffered for years (Nakayama et al., 2016). For example, it was common in their original location to have two or three generations living 
in the same house or in the same complex, and it was very common for the second-generation housewives to have conflict with their mothers-in-law. They suffered from such conflicts, which had few solutions, for a long time before their evacuation. Once they were moved to the temporary housing, they had to live separately from their extended families, because each unit of the temporary housing was designed for just one family, not for multiple generations of the same family. This effectively put an end to the long-lasting conflicts within families, and these housewives told us that they would never return to their original homes-they enjoy their emancipation. Some CCITDP may find their inevitable relocation as an opportunity to be free from old customs, either in the same context as the above-mentioned displaced in Fukushima or in different contexts altogether.

\subsection{Educating CCITDP's Children}

Takesada (2009) found that the provision of better education for children held the greatest importance for migrants since as early as the 1950s. Better education facilities after relocation were also a priority among recent migrants in Laos (Souksavath \& Nakayama, 2013) and Indonesia (Agnes, Solle, Said, \& Fujikura, 2009). The CCITDP may have the same priority when choosing their destination.

CCITDP should be shown more than one destination option within the nation to which they would relocate; the best destination for the first generation of CCITDP may not necessarily be the best destination for their children. Working in the countryside as a laborer at a large plantation (if such an option were offered) may result in more job security and a quieter life, which may bear a greater resemblance to CCITDP' way of life before their relocation. Starting a life in a large city, on the other hand, may be entirely new for CCITDP from a small atoll. On the other hand, living in a city may mean better education opportunities for their children. Selecting one of these options should be left up to the CCITDP.

\section{Discussions}

\subsection{Magnitude of Funds Required to Address the Livelihood Rehabilitation of CCITDP Compared to Protracted Refugees}

The Asian Development Bank (2006) reviewed three development projects in the Philippines (the Sixth Road Project, the Southern Philippines Irrigation Sector Project, and the Pasig River Environmental Management and Rehabilitation Sector Development Program) in which resettlement was inevitable, and they discovered that the cost of resettlement within the same country was $\$ 3,608, \$ 11,428$, and $\$ 8,333$ USD per family, respectively. The cost to resettle one family would differ largely from one country to another, and it would also depend on the nature and location of the development project. Still, these numbers may be indicative of the magnitude of the costs required for one displaced family.

Other researchers have estimated the cost of accommodating the recent inflow of Syrian refugees. Williams (2016) suggested that the annual cost (in USD) per refugee in Jordan was $\$ 3,000$ for food, water, education, and opportunity for employment, whereas in Germany or Austria it was estimated to be over $\$ 30,000$. In Canada, the federal government has met the annual cost of $\$ 4,000 \mathrm{CAD}$ (about $\$ 3,000$ USD) per refugee (Coyle, 2015). Assuming the 
average Syrian family has five members, the annual cost of hosting each family in a developed country can range from $\$ 15,000$ to $\$ 150,000$ USD. This annual cost per family probably surpasses that of relocating the family domestically due to a development project in the developing world.

For non-CCITDP, assistance is required until they either return home or move to another country. On average, major refugee situations lasted for 17 years as of 2003 (United Nations High Commissioner for Refugees, 2004), the duration of which the international donor community must spend huge amounts of money on them. At this stage, how many years CCITDP should be financially supported is an open question. The time required for a climate change refugee family to reestablish their livelihood in a developed country would likely be much shorter than 17 years; therefore, the total cost for the international donor community to support one family of CCITDP should be moderately, if not significantly, less than the amount required to support one family of protracted refugees.

The United Nations High Commissioner for Refugees (2004) reported that "there were 38 different protracted situations in the world, accounting for some 6.2 million refugees in total" (p. 2) at the end of 2003. Considering the annual cost of supporting this huge number of refugees, hosting the entire populations of Tuvalu $(9,000)$, the Republic of the Marshall Islands $(52,000)$, and the Republic of Kiribati $(92,000)$ in the same conditions as other refugees in developed countries sounds quite feasible in terms of the money required annually from the international donor community.

\subsection{Selection of Destination Country}

The best destination country for a family of CCITDP will naturally differ from one family to another, due to various personal factors. Presently, the decision of whether or not to accept a refugee family into a particular developed country is left to that country; refugees have little power to select their destination.

Ideally, CCITDP should be given the option to choose from multiple countries, if this is realistically feasible. CCITDP should be given as many details as possible, including the potential advantages and disadvantages of possible destination countries.

Jones and Teytelboym (2016) proposed the establishment of a matching system between refugees and possible destination countries, "which can both give refugees choices over where they are to be protected and enable states to manage the sharing of responsibility for granting asylum in a way which is equitable and efficient" (p. 80). Establishing a similar system for CCITDP should be considered to better address their needs and aspirations.

\section{Acknowledgement}

This study was supported by KAKENHI (16H03320) and the University of Tokyo Graduate School of Frontier Sciences. 


\section{References}

Agnes, R. D., Solle, M. S., Said, A., \& Fujikura, R. (2009). Effects of construction of the Bili-Bili Dam (Indonesia) on living conditions of former residents and their patterns of resettlement and return. International Journal of Water Resources Development, 25(3), 467-477. http://dx.doi.org/10.1080/07900620902965186

Asian Development Bank. (2006). Asian Development Bank's involuntary resettlement safeguards: Project case studies in the Philippines. Manila, Philippines: Author.

Asian Development Bank. (2012). Addressing climate change and migration in Asia and the Pacific. Mandaluyong City, Philippines: Author.

Betzold, C. (2015). Adapting to climate change in small island developing states. Climatic Change, 133(3), 481-489. http://dx.doi.org/10.1007/s10584-015-1408-0

Biermann, F., \& Boas, I. (2010). Preparing for a warmer world: Towards a global governance system to protect climate refugees. Global Environmental Politics, 10(1), 60-88. http://dx.doi.org/10.1162/glep.2010.10.1.60

Coyle, J. (2015, November 18). Weighing the costs and values of Canada's Syrian refugee pledge. The Star Online. Retrieved from https://www.thestar.com/news/canada/2015/11/18/weighing-the-costs-and-values-of-canadassyrian-refugee-pledge.html

Durková, P., Gromilova, A., Kiss, B., \& Plaku, M. (2012). Climate refugees in the 21st century. Vienna: Regional Academy on the United Nations.

EACH-FOR. (2008). Preliminary findings from the EACH-FOR project on environmentally induced migration. Environmental Change and Forced Migration Scenarios Project. Retrieved from https://proyectoambientales.files.wordpress.com/2011/05/each-for_preliminary_findings_-_fi nal_version.pdf

El-Hinnawi, E. (1985). Environmental refugees. Nairobi, Kenya: United Nations Environment Programme.

Faist, T., \& Schade, J. (Eds.). (2013). Disentangling migration and climate change: Methodologies, political discourses and human rights. New York: Springer. http://dx.doi.org/10.1007/978-94-007-6208-4

Fukushima nuclear evacuees fall below 100,000. (2016, January 9). The Japan Times. Retrieved http://www.japantimes.co.jp/news/2016/01/09/national/fukushima-nuclear-evacuees-fall-100 $000 /$

Hossain, M., Sarker, T., \& McIntosh, M. (Eds.). (2013). The Asian century, sustainable growth and climate change. Cheltenham, UK: Edward Elgar Publishing Limited.

Jones, W., \& Teytelboym, A. (2016). Choices, preferences and priorities in a matching system 
for refugees. Under review.

Kolmannskog, V. O. (2008). Future floods of refugees: A comment on climate change, conflict and forced migration. Oslo, Norway: Norwegian Refugee Council. Retrieved from http://www.adaptationlearning.net/sites/default/files/resource-files/CCconflictandmigartion

NorwayRefugeeCouncil_REPORT_20101026133312_2.pdf

Kothari, U. (2003). Staying put and staying poor? Journal of International Development, 15(5), 645-657. http://dx.doi.org/10.1002/jid.1022

Krokfors, C. (1995). Poverty, environmental stress and culture as factors in African migrations. In J. Baker \& T. A. Aida (Eds.), The migration experience in Africa. Gotab, Sweden: Nordiska Afrikainstitutet.

McLeman, R., \& Smit, B. (2006). Migration as an adaptation to climate change. Climatic Change, 76(1), 31-53. http://dx.doi.org/10.1007/s10584-005-9000-7

Minas, H., Kakuma, R., San Too, L., Vayani, H., Orapeleng, S., Prasad-Ildes, R., ... Oehm, D. (2013). Mental health research and evaluation in multicultural Australia: Developing a culture of inclusion. International Journal of Mental Health Systems, 7(1), 23. http://dx.doi.org/10.1186/1752-4458-7-23

Mutton, D., \& Haque, E. (2004). Human vulnerability, dislocation and resettlement: Adaptation processes of river-bank erosion-induced displacees in Bangladesh. Disasters, 28(1), 41-62. http://dx.doi.org/10.1111/j.0361-3666.2004.00242.x

Nakayama, M. (1998). Post-project review of environmental impact assessment for Saguling Dam for involuntary resettlement. International Journal of Water Resources Development, 14(2), 217-229. http://dx.doi.org/10.1080/07900629849411

Nakayama, M., \& Fujikura, R. (Eds.). (2014). Restoring communities resettled after dam construction in Asia. Abingdon, UK: Routledge.

Nakayama, M., Yoshida, T., \& Gunawan, B. (2000). Improvement of compensation system for involuntary resettlers of dam construction projects. Water Resources Journal, 206, 80-93.

Nakayama, M., Yoshioka, N., Fujibayashi, H., \& Bruch, C. (2016). Factors Affecting Livelihood Re-Establishment of Climate Change Induced Transboundary Displaced Persons. International Journal of Social Science Studies, 4(9), 40-48. http://dx.doi.org/ 10.11114/ijsss.v4i9.1744

Oliver-Smith, A., \& Shen, X. (Eds.). (2009). Linking environmental change, migration \& social vulnerability (SOURCE No. 12/2009). Bonn, Germany: UNU-EHS.

Reuveny, R. (2007). Climate change-induced migration and violent conflict. Political Geography, 26(6), 656-673. http://dx.doi.org/10.1016/j.polgeo.2007.05.001

Skeldon, R. (2002). Migration and poverty. Asia Pacific Population Journal, 17(4), 67-82.

Skeldon, R. (2014). Migration and development: A global perspective. Abingdon, UK: 
Routledge.

Souksavath, B., \& Nakayama, M. (2013). Reconstruction of the livelihood of resettlers from the Nam Theun 2 hydropower project in Laos. International Journal of Water Resources Development, 29(1), 71-86. http://dx.doi.org/10.1080/07900627.2012.738792

Takesada, N. (2009). Japanese experience of involuntary resettlement: Long-term consequences of resettlement for the construction of the Ikawa Dam. International Journal of Water Resources Development, 25(3), 419-430. http://dx.doi.org/10.1080/07900620902965459

United Nations High Commissioner for Refugees (2004). Protracted Refugee Situations, EC/54/SC/CRP.14, 10 June 2004, Geneva: United Nations High Commissioner for Refugees

Warner, K., \& Laczko, F. (2008). A global research agenda. Forced Migration Review, (31), 59-60.

Webber, M., \& Barnett, J. (2010). Accommodating migration to promote adaptation to climate change. Policy Research Working Paper 5270. http://dx.doi.org/10.1596/1813-9450-5270

Wendle, J. (2015, December 17). The Ominous Story of Syria's Climate Refugees. Scientific America. Retrieved from http://www.scientificamerican.com/article/ominous-story-of-syria-climate-refugees/

WHO. (2016). FAQs: Fukushima five years on. Retrieved from http://www.who.int/ionizing_radiation/a_e/fukushima/faqs-fukushima/en/

Williams, R. (2016, March 13). Syrian refugees will cost ten times more to care for in Europe than in neighboring countries. Independent. Retrieved from http://www.independent.co.uk/voices/syrian-refugees-will-cost-ten-times-more-to-care-for-in -europe-than-in-neighboring-countries-a6928676.html

World Bank. (1996, March). Resettlement and development; The Bankwide review of projects involving involuntary resettlement, 1986-1993 (Environment Department working papers No. 32). Washington, DC: Author.

\section{Copyright Disclaimer}

Copyright for this article is retained by the author(s), with first publication rights granted to the journal.

This is an open-access article distributed under the terms and conditions of the Creative Commons Attribution license (http://creativecommons.org/licenses/by/3.0/). 